\title{
PERIBAHASA MINANGKABAU DALAM MEME DI INSTAGRAM
}

\author{
Melani Niko Sari ${ }^{*}$, Wasana ${ }^{2}$, Eka Meigalia ${ }^{3}$ \\ melanisari979@gmail.com* \\ Fakultas Ilmu Budaya Universitas Andalas, 1,2,3
}

\begin{abstract}
ABSTRAK
Artikel ini mendeskripsikan peribahasa Minangkabau dalam bentuk meme di Instagram. Menggunakan kajian semiotika, meme yang diperoleh terlebih dahulu dipilih dan dikelompokkan berdasarkan ragam visualnya. Dengan sampel yang diperoleh melalui tagar tertentu, diperoleh hasil ragam visual meme peribahasa Minangkabau dalam Instagram berbentuk tulisan dan meme dengan tulisan dan gambar. Meme berbentuk teks dan gambar dikelompokkan lagi dalam meme dengan gambar yang beranalogi dengan teks dan meme dengan gambar yang tidak beranalogi dengan teks. Secara keseluruhan meme peribahasa Minangkabau umumnya tidak hanya mampu untuk membangkitkan kembali nilai-nilai tradisional pada ungkapan tradisional masyarakat Minangkabau.
\end{abstract}

Kata kunci: Meme, Peribahasa, Minangkabau, Semiotika.

\section{MINANGKABAU PROVERBS MEME IN INSTAGRAM}

\section{ABSTRACT}

This article describes Minangkabau proverbs in the form of memes on Instagram using a semiotic study. The memes obtained were selected and grouped based on their visual variety. With samples obtained through specific hashtags, the visual variety of Minangkabau proverb memes on Instagram is written and memes with text and pictures. Memes in the form of text and images are further grouped into memes with images analogous to text and memes with images that are not analogous to text. Overall, Minangkabau proverb memes are generally not only able to revive traditional values in the Minangkabau people's traditional expressions.

Keywords: Meme, Proverbs, Minangkabau, Semiotics

Jurnal Elektronik WACANA ETNIK - Vol 8 No 2 2019, (143 - 155) p ISSN 2089-8746, e ISSN 2302-7142

Submit: Juli 2019. Diterima: September 2019. Publikasi: Oktober 2019. 


\section{PENGANTAR}

Seiring dengan pesatnya perkembangan teknologi, maka berbagai sarana untuk berbagi informasi juga mengalami perkembangan yang sangat pesat. Lahirnya media-media yang banyak digunakan oleh kaum milenial untuk menunjukkan kreativitas yang mereka miliki. Kreativitas ini memiliki nilai-nilai positif untuk mendukung tetap lestarinya suatu budaya. Perkembangan teknologi baik di bidang elektronik maupun media, dianggap mengurangi nilai budaya tradisional.

Pada dasarnya hal ini juga mampu untuk menjadi jembatan bagi budaya tradisional tersebut untuk dapat meningkatkan eksistensinya. Hal ini bisa dilihat dari bagaimana media komunikasi atau yang lebih dikenal dengan media sosial menjadi sarana untuk mengingatkan, meningkatkan, melestarikan, mendokumentasikan, serta mempromosikan suatu budaya tradisional agar bisa diketahui oleh masyarakat pada umumnya, dan generasi penerus budaya tersebut khususnya.

Perubahan pada penggunaan media komunikasi ini dimanfaatkan oleh kreator, salah satunya adalah pada media sosial Instagram. Aplikasi ini digunakan untuk mempublikasikan berbagai hal dalam bentuk foto dan video. Hal ini juga membuktikan bagaimana peribahasa bisa bertahan walaupun dengan adanya perkembangan teknologi yang pesat. Kreator membuat peribahasa yang biasanya kaku lebih menarik untuk dibaca, serta dengan menambah unsur kelucuan yang membuat orang tidak enggan untuk membacanya.

Pada umumnya peribahasa yang berupa tulisan ketika dipublikasikan ke media sosial telah disertai dengan gambar, biasanya antara tulisan dan gambar memiliki keterkaitan. Perubahan yang dilakukan pada peribahasa tidak serta merta menghilangkan makna atau teks yang aslinya, walaupun perubahan peribahasa tersebut, mengalami perubahan pemaknaan pada sebagian pembaca.

Peribahasa merupakan ungkapan tradisional yang mengandung pepatah-petitih, kiasan, dan pantun. Teksteks peribahasa yang lebih bersifat tradisional ini dikembangkan oleh kreator agar menarik untuk para pembaca. Ini dilakukan agar teks atau ungkapan tradisional dari peribahasa tetap ada meskipun mengalami perubahan-perubahan. Kreator membubuhkan visual yang unik, menarik, kekinian, dan lucu untuk menyebarkan suatu peribahasa di media sosial. Publikasi gambar dengan tulisan pada media sosial disebut dengan meme.

Meme adalah ide, perilaku, atau gaya yang menyebar dari satu orang ke orang lain dalam sebuah budaya, meme juga merupakan neologisme pendapat ini dikemukakan oleh Richard Dawkins. Meme adalah bentuk pendek mimeme (dari bahasa Yunani Kuno mimema, "imitasi/tiruan", dari mimeisthai, "mengimitasi", dari mimos, "mime"). Di media sosial meme dengan konten Minangkabau sangat banyak, dan hal ini menarik perhatian pembaca. Jika dihubungkan dengan sastra lisan Minangkabau, meme bisa dikategorikan folklor lisan pada zaman teknologi ini (Listiyorini, 2017).

Pada umumnya meme yang telah dipublikasikan di media sosial Instagram mendapat sambutan ataupun tanggapan yang positif dari pembaca. Hal ini bisa dilihat bagaimana komentar-komentar yang dilontarkan pada meme tersebut. Selain mendapat tanggapan yang positif, peribahasa Minangkabau pada meme juga dimaknai dengan baik 
oleh para pembacanya. Ini menunjukkan bahwa ungkapan tradisional seperti peribahasa Minangkabau masih mendapatkan tempat di hati generasi Minangkabau.

Untuk lebih meningkatkan minat baca dan pengetahuan generasi muda Minangkabau terhadap karya sastra Minangkabau, yang mana dengan adanya meme dengan konten Minangkabau ini daya baca dan kreativitas generasi muda milenial lebih tinggi, daripada membaca buku-buku peribahasa Minangkabau yang asli. Oleh karena itu maka penelitian ini menjadi suatu kajian yang dipilih oleh peneliti untuk diteliti.

\section{KERANGKA TEORI DAN METODE}

Peribahasa merupakan suatu ungkapan tradisional yang dulunya hanya dikuasai oleh sebagian orang dan orang ini disebut sebagai pewaris pasif dan pewaris aktif (Danandjaya, 1991:28). Peribahasa adalah hasil dari perubahan pepatah petitih, dan mengandung kiasan-kiasan Minangkabau. Peribahasa Minangkabau yang telah mengalami perubahan tetap memiliki unsur keasliannya, karena pada dasarnya penyampaian maksud dari peribahasa tetaplah dengan yang aslinya. Makna-makna yang ada dalam peribahasa Minangkabau mengandung nilai yang dapat mendorong masyarakat Minangkabau untuk memelihara tindakan, kebiasaan, perilaku dan sikap dalam kehidupan sehari-hari.

Peribahasa adalah bagian dari budaya masyarakat tradisional. Adanya pembaruan pada budaya-budaya tradisional ini terjadi melalui perkembangan zaman dengan kemajuan teknologi yang semakin canggih. Hal ini memberikan beberapa dampak pada eksistensi budaya tradisional. Hal tersebut juga mempengaruhi sastra lisan. Di mana sastra lisan termasuk pada bagian folklor lisan. Ini sejalan dengan pendapat Danandjaya folklor lisan adalah warisan budaya yang murni diturunkan secara lisan, folklor lisan memiliki beberapa bagian yaitu bahasa rakyat (folk speech) seperti logat, julukan, pangkat tradisional, dan titel kebangsawanan: ungkapan tradisional seperti peribahasa, pepatah dan pemeo: pertanyaan tradisional seperti teka-teki: puisi rakyat seperti gurindam dan syair: cerita prosa rakyat seperti mite, legenda dan dongeng: nyanyian rakyat (Danandjaya, 1991:21).

Kesusastraan dalam budaya Minangkabau banyak mengandung ungkapan-ungkapan yang plastis dan penuh dengan kiasan. Perumpamaan atau ibarat, pepatah, petitih, mamangan dan lain-lain dikategorikan oleh para ahli sebagai peribahasa. Bahkan dalam kehidupan sehari-hari umumnya orang-orang menggunakan ungkapan yang plastis tersebut (Navis, 1984: 229).

Meme yang ada saat ini adalah bagian dari sebuah kreativitas yang diciptakan oleh kreator. Pembuatan meme memiliki berbagai tujuan yang berbeda-beda dari masing-masing kreatornya. Umumnya masyarakat mengenal meme sebagai suatu guyonan yang mengundang gelak tawa.. Akan tetapi kehadiran meme dengan konteks tradisional (peribahasa) memiliki nilai yang lebih positif, daripada meme yang hanya sekedar guyonan semata. Meme yang ada di media sosial tidak selalu dalam bentuk tulisan dan gambar, namun ada juga meme dalam bentuk tulisan saja tanpa menggunakan gambar. selain pemaknaan meme pada tulisan, perlu juga diketahui konteks dan pengetahuan yang terkandung dalam meme tersebut. Peribahasa Minangkabau sebagai salah satu konten meme membutuhkan cara berbeda untuk memahaminya daripada memahami media komunikasi konvensional lainnya. 
Penulis menggunakan akun instagram pribadi penulis untuk mencari dan mengumpulkan data. Penelitian terhadap kajian ini menggunakan analisis teks pada meme untuk mengetahui apa saja interpretasi peribahasa Minangkabau yang ada di Instragram.

Penelitian ini dilakukan dengan menghimpun data meme peribahasa Minangkabau yang ada di Instagram. Pengumpulan data ini juga mencakup komentar-komentar yang ada pada meme tersebut. Meme berbahasa Minangkabau dengan konten peribahasa Minangkabau adalah data primer penelitian ini. Sementara itu, data sekunder adalah komentar yang muncul dalam akun pengunggah meme serta pembicaraan tentang meme baik yang berupa kajian ilmiah maupun popular. Semua data atau objek yang telah terkumpul dan di screenshots dari Januari hingga Juni 2019 dengan tagar \#pepatahminang, \#minang, \#urangawak, \#otalapau, \#petatahpetitihminangkabau, \#kiasanminang, \#quoteminang, \#pituahminang, \#mememinang, \#anaklapau, dan \#pepatah tanpa batas waktu yang diunggah.

Sebelum dianalisis, meme terlebih dahulu dipilih dan dikelompokkan berdasarkan bentuk visualnya, yaitu meme dengan dominasi teks atau gambar. Analisis dilakukan menggunakan teori semiotik Charles Sanders Peirce dan makna dalam konteks komunikasi. Dalam hal ini, makna peribahasa Minangkabau dalam meme dibandingkan dengan makna peribahasa Minangkabau sebenarnya. Analisis interpretasi dan hubungan visual antara teks dengan gambar dalam meme didukung oleh data sekunder berupa komentar-komentar yang muncul dalam akun pengunggah meme.

\section{HASIL DAN PEMBAHASAN}

Instragram merupakan salah satu media untuk berbagi foto dan video. Salah satunya adalah meme, meme merupakan ide yang menyebar dari orang ke orang. Meme sebagai salah satu unggahan yang mendapat banyak tempat dan bisa diterima masyarakat, salah satunya adalah meme dengan peribahasa Minangkabau. Selain memiliki makna yang dalam, meme juga menjadi perwakilan bagi masyarakat untuk memahami dan menunjukkan eksistensi budayanya.

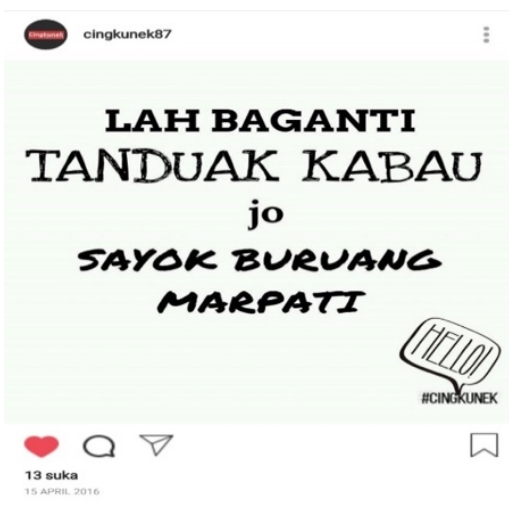

GAMBAR 1. Berganti (sumber: IG @Cingkunek87)

Pada meme peribahasa di atas yang diposting oleh akun@cingkunek87 pada tanggal 15 April 2016, dengan like pada meme sebanyak 13 orang. Teks lah baganti tanduak kabau jo sayok buruang marpati dapat diartikan 'telah 
berganti tanduk kerbau dengan sayap burung merpati'. Meme ini hanya berisi teks tanpa gambar ilustrasi. Latar peribahasa ini berwarna putih dengan warna teks yang gelap. Pengunggah juga menggunakan huruf yang besar dan kecil dalam teksnya. Selain itu pengunggah juga menampilkan nama akunnya pada pojok kanan bawah meme.

Meme gambar 1 adalah teks tanpa gambar ilustrasi. Latar peribahasa ini berwarna putih dengan warna teks yang gelap. Pengunggah juga menggunakan huruf yang besar dan kecil dalam teksnya. Selain itu pengunggah juga menampilkan nama akunnya pada pojok kanan bawah meme, serta pengunggah menempatkan kata hello dalam gelembung yang berupa seperti sapaan dari pengunggah karena berada tepat di atas nama pemilik akun.

Peribahasa pada meme ini diartikan sebagai suatu hal yang dulunya bersifat tradisional. Pada peribahasa di atas adalah salah satu meme yang hanya menampilkan teks. Secara umum meme dengan pola seperti di atas lebih cenderung kepada font yang terlihat artistik, dengan tidak menggunakan latar atau gambar-gambar yang membuat meme terlihat ramai. Pemilihan warna cerah pada meme menunjukkan sesuatu yang positif, dan penuh harapan.

Simbol meme ini adalah situasi dibangunnya Tugu Merpati Perdamaian di salah satu titik pantai Kota Padang. Meme ini muncul tepat tiga hari setelah peresmian Tugu Merpati Perdamaian yang diposting oleh akun (a) cingkunek87. Hal ini berkaitan dengan adanya pembangunan Tugu Merpati Perdamaian di pantai Padang. Ikon yang digunakan adalah merpati sedangkan Minangkabau identik dengan kerbau. Hal ini berangkat dari salah satu pendapat di Tambo Alam Minangkabau tentang asal usul nama Minangkabau yang berasal dari peristiwa adu kerbau. Kemudian dari peristiwa ini, tanduk kerbau seperti menjadi simbol bagi masyarakat Minangkabau. Ini bisa dilihat pada gonjong Rumah Gadang Minangkabau dan pada beberapa pakaian tradisional masyarakat Minangkabau (Navis, 1984: 51). Pembangunan ini sempat menjadi perhatian oleh ketua Majelis Tinggi Kerapatan Adat Alam Minangkabau (MTKAAM), menurut MTKAAM hal ini akan membuat penilaian masyarakat Sumatera Barat tentang sebuah perdamaian terpecah (Haluan, 21 April 2016). Akan tetapi banyak pihak yang mendukung tentang pembangunan monumen merpati perdamaian ini, karena pada dasarnya pembangunan ini murni untuk menyampaikan pesan perdamaian.

Indeks meme peribahasa Gambar 1 adalah tentang bagaimana kreator menunjukkan ungkapan kekecewaan. Hal ini kontras dengan makna peribahasa dan pemilihan warna pada meme, ini bisa diartikan bahwa dari negatifnya makna meme, diharapkan menjadi lebih baik atau positif dengan penggunaan warnanya. Peribahasa ini artinya sudah berganti tanduk kerbau dengan sayap burung merpati, menunjukkan bahwa adanya pergeseran dari penggunaan simbol-simbol adat yang dulu dianggap penting. Tanduk kerbau menjadi salah satu asal usul yang menjadi cikal bakal Minangkabau. Hal ini dikisahkan dalam tambo alam Minangkabau. Pada meme ini pengunggah menitikberatkan pada pemahaman pembaca terhadap meme tersebut. Pembaca tidak selalu menyampaikan pemahamannya melalui kolom komentar. Kebanyakan ada juga yang hanya membaca dan memahami artinya untuk dirinya sendiri. 


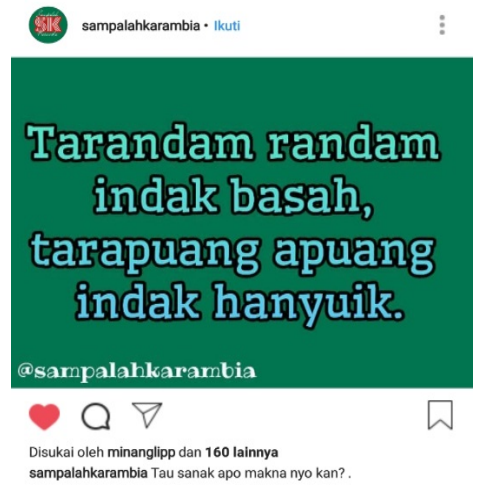

GAMBAR 2. Air. (sumber: IG @sampalahkarambia)

Tarandam tak basah, tarapuang tak anyuik, artinya misalnya suatu perkara atau pekerjaan yang tak tentu ujung pangkalnya atau belum ada akhirnya (Navis, 1996: 64). Meme ini diposting oleh akun @sampalahkarambia, pada tanggal 28 Mei 2019, dengan like pada meme sebanyak 161 orang. Arti dari meme peribahasa ini di atas adalah terendam tidak basah, terapung tidak hanyut. Meme ini hanya menampilkan latar warna polos berwarna hijau. Teks pada meme identik dengan warna hijau terang dengan penggunaan garis tepi pada huruf-huruf teks berwarna hitam. Pengunggah juga menampilkan nama akunnya pada meme ini di pojok kiri bawah dengan warna teks putih.

Meme tersebut adalah meme yang hanya menampilkan teks dan warna latar yang cukup pekat. Umumnya meme dengan visual di atas lebih cenderung menegaskan pada pemaknaan teks. Pengunggah menggunakan warna hijau tua atau hijau pekat untuk latarnya tanpa ada tambahan emoticon ataupun tanda baca lain selain koma dan titik. Tarandam-randam indak basah adalah sebuah perumpamaan dari kering walaupun berendam dalam air, dan untuk tarapuang-rapuang indak hanyuik adalah sebuah perumpamaan dari tidak hanyutnya benda yang berada di atas aliran air.

Peribahasa pada Gambar 2 mengungkapkan tentang bagaimana suatu hal yang telah menjadi masalah tidak kunjung diselesaikan. Dalam tahap penyelesaian pun selalu dilalaikan atau tidak dilakukan dengan serius. Selain itu peribahasa pada meme tersebut menunjukkan jika suatu persoalan tidak kunjung diselesaikan maka persoalan itu akan tetap ada, karena persoalan apa pun yang sedang dihadapi perlu ditemukan solusi penyelesaiannya. Pada peribahasa ini cenderung mengarah kepada sebuah penyelesaian yang disegerakan dan dikerjakan dengan serius.

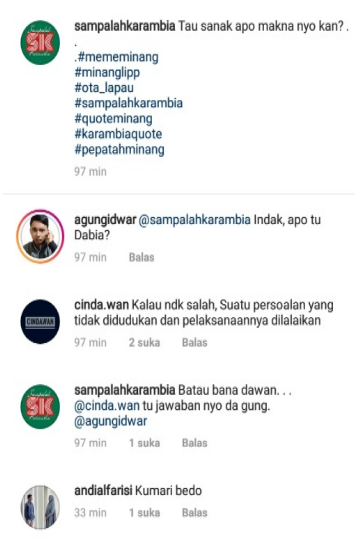


GAMBAR 3. Contoh komentar

@agungidwar@sampalahkarambia indak,apo t dabia?

@ cinda.wan kalua ndk salah, suatu persoalan yang tidak didudukan dan pelaksanaannya dilalaikan

@sampalahkarambia bataubana dawan...@cinda.wantu jawabannyoda gung. @agungidwar

@andialfarisi kumara bedo

Simbol pada meme peribahasa ini kreator menggunakan latar dan tulisan berwarna biru dicampur dengan hijau. Hal ini menunjukkan tidak adanya keterkaitan. Latar dan tulisan hanya sebatas pelengkap tanpa adanya hubungan yang mewakilkan satu sama lainnya. Sedangkan untuk pemaknaan meme ini pengunggah memberikan pertanyaan kepada para pembacanya, apakah mengetahui maksud dari peribahasa tersebut. Pertanyaan ini dijawab oleh salahsatufollower@sampalahkarambia yaitu akun@cinda.wan yang mana arti dari peribahasa itu adalah tentang kelalaian terhadap sesuatu. Dilihat dari beberapa balasan yang ada pada kolom komentar, ada dari pembaca yang menyimpulkan maksud dari peribahasa ini dan ada juga para pembaca yang tidak tahu maksud dari peribahasa tersebut. Hal ini menunjukkan adanya pemahaman tentang peribahasa yang masih diketahui oleh beberapa orang.

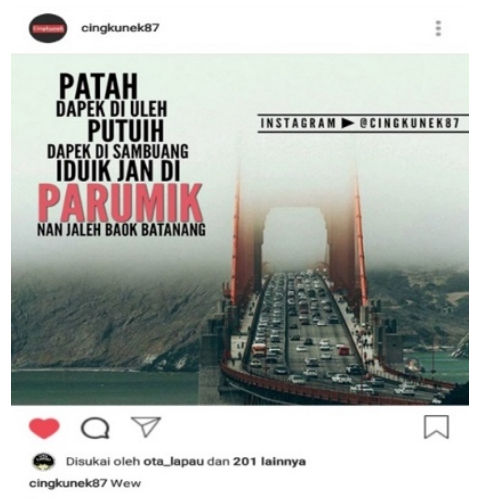

GAMBAR 4. Rumit (sumber: IG @cingkunek87)

Meme peribahasa ini diunggah oleh akun@cingkunek87, pada tanggal 5 Oktober 2016. Jumlah like pada meme ini sebanyak 202. Teks pada meme patah dapek diuleh putuih dapek disambuang iduik jan di parumik nan jaleh baok batanang dapat diartikan 'patah dapat diulas (sambung) putus dapat disambung hidup jangan diperumit yang jelas bawa tenang'. Pada kehidupan sehari-hari peribahasa ini sering digunakan untuk menyemangati dan menenangkan orang yang sedang banyak masalah.

Meme peribahasa di atas diberi ilustrasi jembatan besar yang sedang dilalui banyak kendaraan. Jembatan dengan warna merah dan di bawahnya terdapat sungai. Jembatan ini menghubungkan dua daratan yang terpisahkan oleh sungai. Teks pada tulisan menggunakan font yang tebal dengan warna gelap untuk teks dan warna yang mencolok untuk kata parumik. Latar warna pada meme ini umumnya menggunakan warna gelap terang pada bagian atas gambar. Pengunggah juga menampilkan informasi akunnya dalam ilustrasi gambar meme.

Patah kapak batungkek paruah, patah paruah batilakan (tidak berputus asa, selalu berikhtiar, misalnya kalau tidak mungkin dengan jalan yang ini, berangkali dengan jalan yang itu dapat dicapai yang diharapkan tersebut) (Navis, 1996: 368). Meme pada Gambar 4 adalah arti peribahasa patah dapat di ulas, putus dapat disambung, hidup jangan 
diperumit, yang jelas dibawa tenang. Meme di atas adalah salah satu meme yang menampilkan teks dan gambar. Teks yang ada pada meme menggunakan font tebal dan tipis pada tulisannya. Gambar yang ada pada meme memberikan kesan yang sesuai dengan teksnya. Kata parumik (rumit) menjadi perwakilan dari semua teks, begitu pula dengan gambar pada meme. Patah dapat diulas menunjukkan sesuatu yang menjadi jalan keluar, begitu pun dengan kata putus dapat disambung keduanya menjadi berkesinambungan dengan kata yang berbeda tetapi maksud dari keduanya sama. Jika digabungkan dengan kata hidup jangan diperumit bisa diartikan bahwa akan selalu ada masalah, akan tetapi setiap masalah juga selalu memiliki jalan penyelesaian. Banyak hal yang harus dihadapi jangan sampai membuat diri sendiri kesusahan, karena selalu ada jalan penyelesaiannya.

Ikon meme 4 adalah sebuah jembatan dan kendaraan yang sedang padat di atasnya menunjukkan adanya kehidupan dan sesuatu yang rumit, jika segala sesuatu menjadi satu pikiran. Jembatan menjadi sambungan antara daratan yang satu dan yang lainnya, hal ini menunjukkan bahwa adanya hubungan antara satu sama lainnya. Sedangkan air di bawah jembatan mewakilkan sebuah ketenangan.

Jembatan pada meme adalah Golden Gate Bridge, yang berada di teluk Golden Gate, jembatan ini menghubungkan antara kota San Francisco dan tanjung Marin California. Jembatan ini mulai dibangun pada tahun 1993 dan selesai pada tahun 1937. Golden Gate Bridge merupakan rancangan dari Joseph Strauss. Keindahan jembatan yang berada di teluk Golden Gate ini terletak pada warna dan keberadaannya yang menghadap pulau Alcatraz yang dulu berfungsi sebagai penjara. Selain memiliki keindahan yang memukau jembatan ini juga menyimpan cerita kelam. Hal ini karena Golden Gate Bridge banyak dijadikan sebagai tempat untuk bunuh diri, kasus bunuh diri yang terjadi di jembatan ini bahkan sudah mencapai ribuan orang. Penggunaan warna jingga pada jembatan ini adalah untuk memudahkan kapal yang akan melintas saat kabut menyelimuti teluk Golden Gate (Liputan6, 28 April 2014).

Pemaknaan meme peribahasa Gambar 4 adalah tentang bagaimana kreator mengidentikkan peribahasa dengan gambar. Sesuatu yang rumit pun akan tetap ada jalan penyelesaiannya. Maka untuk setiap urusan-urusan yang sulit untuk dipecahkan jangan gegabah dalam menyelesaikannya. Pikirkan dengan tenang dan cermat hal-hal yang kemungkinan bisa menjadi jalan keluarnya.

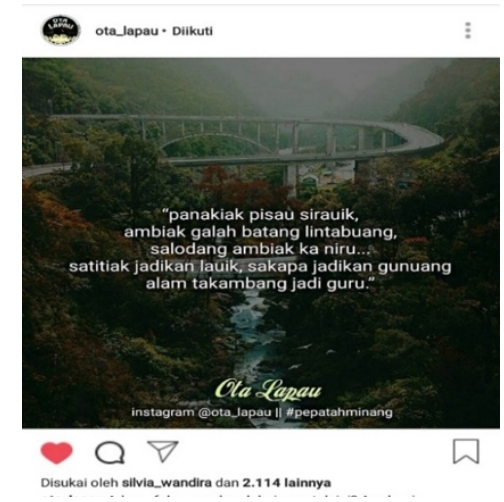

GAMBAR 5. Alam Takambang Jadi Guru (sumber: IG @otalapau) 
Pada meme Gambar 5 di atas pengunggah menggunakan pemandangan alam yang asri. Sebuah jalan yang berada di antara dua bukit yang mana di bawahnya mengalir sungai. Pada ilustrasi ini terlihat warna dedaunan yang memerah serta hijau. Selain sungai, ilustrasi juga dilengkapi dengan pepohonan yang tumbuh di tepian sungai dan juga di bukit kiri kanan jalan. Dikarenakan kedua bukit ini dilalui sungai maka dibangun jalan layang. Pada gambar ilustrasi terlihat di bawah jalan layang terdapat beberapa bangunan, dan kendaraan yang sedang melaju di atas jalan layang. Untuk penggunaan peribahasa ini biasanya dipakai ketika memberikan petuah kepada seseorang. Arti dari peribahasa ini yaitu penakik pisau siraut, ambil galah batang lintabung, seladang ke niru, setitikjadikan laut, sekapal jadikan gunung, alam terkembang jadikan guru. Meme peribahasa ini diposting pada tanggal 27 April 2018 oleh akun @otalapau, dengan like pada meme ini sebanyak 2115. Pengunggah juga mencantumkan nama akun serta tagar pada ilustrasi gambar meme peribahasa di atas.

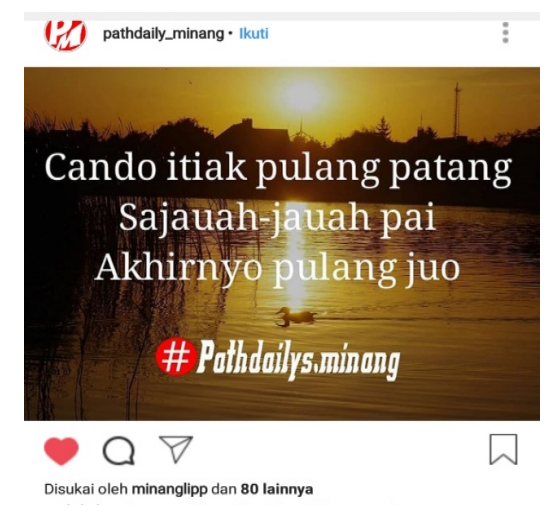

GAMBAR 6. Bagaikan itik pulang sore (sumber: IG @pathdaily_minang)

Meme peribahasa Gambar 6 di atas diunggah oleh akun@pathdaily_minang pada tanggal 2 April 2019, dengan like sebanyak 81 orang. Arti dari meme peribahasa di atas adalah bagaikan itik pulang sore, sejauh-jauhnya pergi, pada akhirnya pulang juga. Pada meme peribahasa di atas umumnya sering digunakan ketika memberikan perumpamaan sebagai petuah. Ilustrasi pada meme menggunakan latar waktu sore hari, tepatnya ketika matahari mulai beranjak ke peraduannya. Pantulan cahaya matahari pada sebuah danau yang mana di danau tersebut terlihat seekor bebek berenang ketepian. Tepian danau yang ditumbuhi rumput tinggi menjadi arah yang dituju oleh si bebek. Ilustrasi pada meme di atas terlihat ada sebuah rumah yang dikelilingi pepohonan. Di sudut kiri gambar juga terlihat sebuah tiang. Dominasi warna pada meme ini lebih cenderung kepada warna keemasan dan gelap. Pengunggah juga menampilkan nama akunnya pada gambar meme. Bak itiak pulang patang (berjalan beriringan seperti itik pulang petang, dikatakan mengenai wanita yang pantatnya berlenggak lenggok waktu berjalan) (Navis, 1996:167).

Ikon pada meme 6 di atas adalah ilustrasi foto danau dan gambar itik yang sedang berenang. Indeks meme adalah gerakan berenang itik yang menimbulkan adanya gelombang pada permukaan air. Simbol meme yaitu kata itik dan gambar itik. Ikon meme peribahasa pada Gambar 6 menggunakan ilustrasi dan teks yang saling berhubungan dan menggunakan aksen warna gelap, remang, dan cerah. Pengunggah meme ini menyertakan ilustrasi yang sama dengan teks pada meme. Hal ini terlihat dari bagaimana seekor itik yang berenang menuju ke daratan di sebuah danau, ini bisa menunjukkan bahwa si itik akan beranjak pulang, matahari yang telah beranjak turun ke peraduannya, ini 
menandakan bahwa hari telah beranjak petang, pantulan warna jingga juga menandakan bahwa waktu petang telah masuk.

Indeks dari peribahasa yang ditulis pada meme ini berarti bahwa betapa pun jauhnya seekor itik pergi mencari makan dan lain-lain, jika hari telah petang dia akan tetap pulang. Cara itik ketika berjalan yang teratur dan selalu mengikuti barisan di depan menunjukkan suatu keteraturan. Keteraturan memiliki artian yang disiplin dan rapi. Hal ini menunjukkan bahwa makna pada peribahasa ini yaitu sejauh apa pun seseorang pergi, baik itu merantau untuk bekerja dan lain-lain. pada suatu hari akan ada saat seseorang itu akan kembali ke kampung halamannya. Seperti juga yang pergi dari kita akan kembali juga pada kita. Peribahasa ini mengajarkan untuk selalu berbaik sangka terhadap segala sesuatu. Peribahasa sejenis juga terlihat pada sejauh-jauh bangau terbang pulangnya ke kubangan jua. Kedua peribahasa di atas menunjukkan hal atau makna yang sama, makna keduanya mengungkapkan tentang pergi yang pada akhirnya akan tetap kembali.

Simbol pada unggahan ini yaitu gambar itik yang berenang ketepian dan menimbulkan riak pada permukaan air danau yang mana maknanya kembali pulang. Penggunaan simbol ini menunjukkan bahwa pengunggah menggambarkan tentang suatu motivasi jika pergi maka suatu saat akan tetap kembali. Selain itu, meskipun berada pada tempat yang terlihat tenang tetapi pada dasarnya akan ada saat tempat tersebut berubah menjadi tempat yang menimbulkan berbagi hal yang tidak membuat nyaman sama sekali, ini bias dikarenakan perbuatan kita sendiri atau pun lainnya. Pada unggahan ini juga pengunggah menitikberatkan pemaknaan terhadap pembacanya, tetapi pengunggah memberikan arahan melalui kolom keterangan agar selalu berpikiran positif. Ini dilakukan untuk menggiring pola pikir para pembaca.

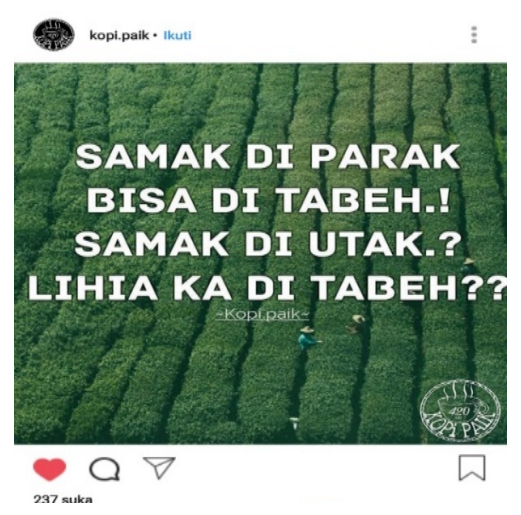

GAMBAR 7. Semak (sumber: IG @kopi_paik)

Meme peribahasa Gambar 7 di atas diunggah oleh akun @kopi.paik yang memiliki like sebanyak 237, dan diunggah pada tanggal 19 Februari 2017. Arti dari peribahasa ini adalah Semak di kebun, Bisa di potong, Semak di kepala, Leher mau dipotong. Meme peribahasa di atas umumnya dipakai ketika seseorang yang ditimpa banyak masalah. Ilustrasi pada gambar di atas menunjukkan sebuah kebun teh yang sedang menghijau dan sedang dipetik oleh beberapa orang pemetik teh. Pola tanam pada teh yang membentuk garis-garis lurus untuk memberikan ruang pada pemetik teh agar bisa dengan mudah memetiknya. Penggunaan warna pada ilustrasi meme ini cenderung kepada warna yang lembut dan sejuk ketika dilihat. Pengunggah juga menampilkan informasi atau nama akunnya pada meme 
ini, selain itu pengunggah menggunakan warna yang cerah pada teks yang ada dalam meme ini. Samak-samak disiangi, rimbun-rimbun ditutuah. Tutuah (tutuh) yaitu memangkas atau memotong cabang-cabang pohon, kalau banyak semak disiangi (dibersihkan), kalau rimbun dipangkas, (barang milik kita harus dijaga (dirawat), agar selalu dalam keadaan baik)) (Navis, 1996: 424).

Ikon meme pada gambar 7 menggunakan ilustrasi dan tulisan tidak mewakili peribahasa yang terdapat pada meme. Ilustrasi pada meme ini terlihat sebuah kebun teh dan beberapa orang pemetik teh yang sedang bekerja. Warna hijau pekat dan dengan font teks pada meme yang berwarna putih menunjukkan kekontrasan warna. Tetapi kedua warna ini sama-sama menunjukkan hal yang positif, warna hijau yang enak dipandang dan menyejukkan, sedangkan warna putih yang bersih dan cenderung dianggap suci.

Peribahasa pada gambar 7, samak di utak, lihia ka di tabeh adalah bagian dari perumpamaan seseorang yang memiliki banyak sekali masalah yang tidak penting dalam pikirannya. Kemudian berangkat dari ini pengunggah meme memberikan semacam arahan dalam berpikir untuk pembaca melalui kalimat samak di parak bisa ditabeh, dengan perumpamaan diibaratkan dengan semak, sifat semak yang biasanya menjadi parasit atau sesuatu yang dianggap mengganggu. Pada umumnya orang-orang akan menyingkirkan atau membersihkan semak-semak yang memang dianggap mengganggu dan tidak enak dipandang. Hal ini kemudian memberikan kesan kepada para pembaca bahwa pikiran-pikiran yang memang tidak penting sebaiknya jangan terlalu dipikirkan, karena hal ini bisa membuat stres dan semakin sulit dalam menyelesaikan masalah-masalah yang lebih penting.

Simbol pada meme ini, teks dan gambar tidak menunjukkan adanya keterkaitan satu sama lain. Namun melalui gambar ini pegunggah menyelipkan pesan bahwa apa pun yang terjadi, apa pun masalah yang dihadapi sebaiknya berpikirlah dengan tenang dan jernih. @kopi_paik juga memberikan penekanan pada kolom keterangannya dengan kalimat "hahahaa, ijaaaan dicubo sanak". Ini dilihat dari penggunaan warna hijau yang memang mengisyaratkan kedamaian, serta warna putih pada teks adalah sebuah kejernihan. Pesan ini pun juga langsung disampaikan pengunggah melalui kolom keterangan agar para pembaca tidak sampai mencoba apa yang ditulis pada meme. Pada kolom keterangan pengunggah atau kreator membubuhkan kata hahaha, ijan di cubo sanak. Kata yang dibubuhkan pengunggah walaupun terlihat seperti bercanda, namun pengunggah menitipkan pesan pada kata itu yaitu jangan melakukan hal yang nantinya akan disesali.

Salah satu followers dari kopi_paik yaitu@ver.ry memberikan tanggapan yang bernada candaan dan pertanyaan kepada akun kopi_paik. Candaan yang ditulis oleh Verry menandakan bahwa kata lihia ka di tabeh tentang hari raya Idul Adha, saat dilakukan penyembelihan hewan kurban. Hal ini sama pada kata tabeh, karena kata tersebut bisa juga diartikan sebagai potong. Candaan yang berupa pertanyaan dari Verry pada dasarnya menunjukkan kalau sebenarnya ia paham akan maksud dari meme tersebut.

\section{PENUTUP}

Meme peribahasa Minangkabau yang ditemukan di Instagram adalah berupa tipologi Peirce. Secara keseluruhan meme peribahasa Minangkabau tersebut terbatas pada konvensi masyarakat Minangkabau dengan kiasan 
yang digunakannya. Meme peribahasa Minangkabau pada Instagram ditemukan empat bentuk meme peribahasa Minangkabau: meme peribahasa Minangkabau berbentuk teks, meme peribahasa Minangkabau berbentuk teks dan gambar. Meme berbentuk teks dan gambar dikelompokkan lagi dalam meme dengan gambar yang beranalogi dengan teks dan meme dengan gambar yang tidak beranalogi dengan teks. Hal ini dibuktikan dengan pengelompokan bentukbentuk pada data. Data pada penelitian ini memiliki unsur-unsur semiotika yang dikemukakan oleh Peirce yaitu ikon, indeks, dan simbol pada setiap data yang dianalisis dalam skripsi ini. Akan tetapi tidak semua data memiliki tiga sistim tanda sekaligus dalam satu data.

Secara keseluruhan meme peribahasa Minangkabau umumnya tidak hanya mampu untuk membangkitkan kembali nilai-nilai tradisional pada ungkapan tradisional masyarakat Minangkabau. Tetapi juga mampu untuk memberikan interpretasi-interpretasi baru bagi pembaca, meskipun beberapa data mengalami perubahan dari ungkapan sebagaimana aslinya. Tetapi hal ini tidak menghilangkan makna dari peribahasa itu. Kemajuan dalam bidang media komunikasi tidak sepenuhnya berdampak buruk pada budaya tradisional. Adanya sistem komunikasi yang berbasis teknologi internet menjadikan budaya tradisional memiliki tempat untuk menunjukkan lokalitasnya pada dunia, ataupun pada masyarakat pemilik budaya tersebut. Dengan berkembangnya teknologi komunikasi saat ini dapat mendukung untuk tetap lestarinya suatu budaya tradisional. Pada dasarnya perkembangan teknologi informasi telah menjadi jembatan bagi budaya tradisional untuk dapat meningkatkan eksistensinya. Teknologi komunikasi secara tidak langsung telah membantu budaya tradisional dalam mengingatkan, meningkatkan, melestarikan, dan mendokumentasikan, serta mompromosikan budaya tradisional untuk bisa diketahui dan dinikmati masyarakat pada umumnya dan generasi penerus budaya tersebut.

\section{REFERENSI (TNR12)}

Amir, A. (2013). Sastra Lisan Indonesia. Yogyakarta: CV Andi Offset.

Danandjaja, J. (1991). Folklore Indonesia Ilmu Gosip, Dongeng, dll. Jakarta: PT. Pustaka Grafiti Utama.

Djamaris, E. (2002). Pengantar Sastra Rakyat Minangkabau (I). Jakarta: Yayasan Obor Indonesia.

Endaswara, S. (2009). Metodologi Penelitian Folklor. Yogyakarta: Medpress.

Hakimy, I. (1984). 1000 Pepatah-petitih, Mamang-Bidal, Pantun-Gurindam (2nd ed.). Bandung: Remadja Karya CV. Haluan, H. (2016, April 21). Monumen Merpati Perdamaian Disorot. Harian Haluan. Retrieved from https://www.harianhaluan.com/news/detail/52214/monumen-merpati-perdamaian-disorot.

Hananik, L. (2016). Bahasa Minangkabau Pada Meme di Display Picture Blackberry Mesenger Tinjauan Pragmatik. Fakultas Ilmu Budaya, Universitas Andalas.

Huntington, H. E. (2013). Subversive Memes: Internet Memes as a Form of Visual Rhetoric. 14.

Lestari, W. (2018). IRONY ANALYSIS OF MEMES ON INSTAGRAM SOCIAL MEDIA. 10(2).

Listiyorini, A. (2017). WACANA HUMOR DALAM MEME DI MEDIA ONLINE SEBAGAI POTRET KEHIDUPAN SEBAGIAN MASYARAKAT INDONESIA. 16 (Wacana Humor di Media Asing).

Luvitasari, H. (2015). Meme Dagelan di Instagram Tinjauan Sosiolinguistik. Gajah Mada.

Navis, A. (1984). Alam Takambang Jadi Guru. Jakarta: Grafiti Pers.

Nafis, A. (1996). Peribahasa Minangkabau. Jakarta: Intermasa.

Nugraha, A., Hasanah Sudrajat, R., \& Primadani Satria Putri, B. (2015). FENOMENA MEME DI MEDIA SOSIAL: STUDI ETNOGRAFI VIRTUAL POSTING MEME PADA PENGGUNA MEDIA SOSIAL INSTAGRAM. Jurnal Sosioteknologi, 14(3), 237-245. https://doi.org/10.5614/sostek.itbj.2015.14.3.3

Pepen. (2019, January 22). Mulyadi Aktor Utama Percepatan Pembangunan Kelok 9 - Portal Berita Singgalang. Harian Umum Independen Singgalang. Retrieved from https://hariansinggalang.co.id/mulyadi-aktor-utamapercepatan-pembangunan-kelok-9/

Ratna, N. K. (2015). Teori, Metode, dan Teknik Penelitian Sastra. Yogyakarta: Pustaka Pelajar. 
Santosa, P. (1993). Ancangan Semiotika dan Pengkajian Susastra. Bandung: Percetakan Angkasa.

Siska Amelie F Deil. (2014, April 28). Golden Gate Bridge, Jembatan Perenggut Ribuan Jiwa - Bisnis Liputan6.com. Liputan 6. Retrieved from https://www.liputan6.com/bisnis/read/2042964/golden-gate-bridge-jembatanperenggut-ribuan-

jiwa?utm_expid=.9Z4i5ypGQeGiS7w9arwTvQ.0\&utm_referrer=https\%3A\%2F\%2Fid.search.yahoo.com\%2F

Subor, A. (2009). Semiotika Komunikasi. Bandung: PT. Remaja Rosdakarya Offset.

Tinarbuko, S. (2009). Semiotika Komunikasi Visual. Yogyakarta: Jalasutra.

Yudha Manggala P Putra. (2018, February 17). Eloknya Layang Kelok Sembilan Sumbar. Republika Online. Republika. Retrieved from https://www.republika.co.id/berita/gaya-hidup/travelling/18/02/17/p49rt5284eloknya-layang-kelok-sembilan-sumbar

Zoest, P. S. dan A. Van. (1992). Serba-serbi Semiotika. Jakarta: PT. Gramedia Pustaka Utama. 